\title{
Analysis of Grain-Size Selection by Deposit- Feeding Holothurians and Echinoids (Echinodermata) from a Shallow Reef Lagoon, Discovery Bay, Jamaica*
}

\author{
L. S. Hammond“ \\ Zoology Department, University of the West Indies, Mona, Kingston 7, Jamaica
}

\begin{abstract}
The size-frequency distribution of sediments from the foreguts of the aspidochirote holothurians Isostichopus badionotus, Holothuria mexicana and $H$. arenicola, and the spatangoid echinoids Meoma ventricosa and Plagiobrissus grandis, collected in the field, closely resembled those of sediments sampled adjacent to each animal. The differences in graphic mean grain size fell within the range of variability of the available sediment. Laboratory experiments using 2 grades of poorly sorted sand confirmed that $J$. badionotus, H. mexicana, H. arenicola, H. grisea, Actinopyga agassizi and the apodous holothurian Euapta lappa did not discriminate between different size grains. Small and large specimens of the first 3 species showed no difference in the spectrum of grain sizes ingested in the laboratory. Critical evaluation of previous reports reveals no unequivocal evidence of selective feeding by deposit-feeding holothurians. In general, deposit-feeding holothurians and spatangoids appear to be incapable of exercising any preference for particular grain sizes. The significance of the differences in surface texture of the buccal podia between holothurian species is unclear, but texture does not appear to be related to size of food particles in any simple way. It is suggested that feeding may not be a purely mechanical process, as previously thought, but that adhesive mucus on the buccal podia might play a role. In contrast to other deposit-feeding taxa, grain size does not appear to be a significant mechanism for resource partitioning between coexisting species of tropical holothurians; other studies suggest microhabitat differences may be more important.
\end{abstract}

\section{INTRODUCTION}

Preferential ingestion of a particular size of grains from the sediment has been identified in diverse taxa of deposit feeders, including polychaetes (Whitlatch, 1974, 1976; Hylleberg, 1975; Cadée, 1975), amphipods (Fenchel et al., 1975) sipunculids (Hansen, 1978), gastropods (Fenchel et al., 1975) and bivalves (Reid and Reid, 1969; Hylleberg and Gallucci, 1975). In most studies, small grains were preferentially ingested, probably due to the exponential increase of available food with decreasing particle size (Newell, 1965; Hylleberg and Gallucci, 1975). Taghon et al. (1978) confirmed the significance of this behaviour on theoretical grounds, by examining the relationship between assimilation efficiency, food processing rates and the

\footnotetext{
- Contribution No. 178 from the Discovery Bay Marine Laboratory

- Present address: Australian Institute of Marine Science, PMB No. 3, MSO, Townsville, Queensland 4810, Australia
}

costs and benefits of particle-size selection. Under some conditions defined by Taghon et al., selection may be for larger grains, or may be absent. These interactions provide for resource partitioning between co-existing deposit feeders on the basis of grain size, as several studies have empirically demonstrated (Mangum, 1964; Fenchel et al., 1975; Fenchel and Kofoed, 1976; Whitlatch, 1976).

A number of studies on holothurians have purported to show selection for smaller or larger grain sizes (Bertram, 1936; Yanamouti, 1939; Emery et al., 1954; Emery, 1962; Rhoads and Young, 1971; Hauksson, 1979; Roberts, 1979). Other authors (Gardiner, 1904; Trefz, 1958; Glynn, 1965; Yingst, 1974; Powell, 1977 ; Sloan and von Bodungen, 1980), found no evidence for particle-size selection. The results of studies on spatangoid urchins are equally diverse. Nichols (1959) and Chesher (1968, 1969) identified non-selective feeding in a number of species, one of which was shown by Lafon (1953) to select larger grains. Others 
were reported to feed selectively (Nichols, 1959; Lawrence and Ferber, 1971). Few studies have considered the significance of feeding behaviour for resource partitioning in either group. Trefz (1956), Roberts (1979) and Sloan (1979) identified differences in particle size of gut contents of co-existing species of tropical holothurians, and suggested that grain size selection might represent an important mechanism for resource sharing.

In the present study, field investigations of 5 holothurian species, Holothuria mexicana Ludwig, $H$. arenicola Semper, Isostichopus badionotus Selenka, Actinopyga agassizi Selenka and Euapta lappa Muller, and the spatangoid echinoids Meoma ventricosa Lamarck and Plagiobrissus grandis Gmelin, were undertaken to determine the ability of each species to discriminate between different-sized grains in its natural habitat. Laboratory experiments offered a range of grain sizes to the 5 holothurian species and to $H$. grisea Selenka. Scanning electron microscope examination of the feeding tentacles of the holothurians and spatangoids was used to assess possible relationships between tentacle surface texture and grain size selection.

\section{MATERIALS AND METHODS}

\section{Field Collections}

A description of the Discovery Bay Reef environments was given by Woodley and Robinson (1977). Sampling Sites 1 and 2 (Fig. 1), with moderately sorted medium sand substrates, were described by Hammond (1982). Approximately $10 \mathrm{~g}$ dry weight of sediment were taken from the foregut (the first $10 \mathrm{~cm}$ or less) of

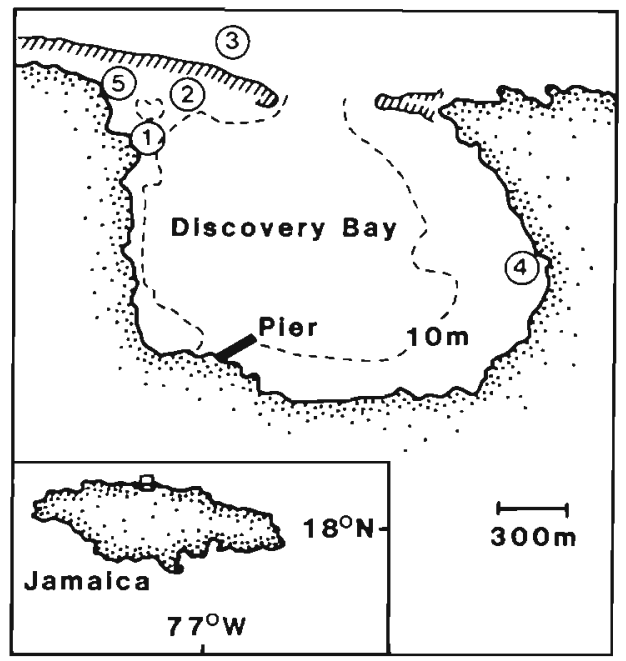

Fig. 1. Map of Discovery Bay, showing the shallow eastern and western lagoons behind the fringing reef (cross-hatched), and locations of study sites dissection specimens of Holothuria mexicana, Isostichopus badionotus and $H$. arenicola from Site 1 , and H. arenicola, Meoma ventricosa and Plagiobrissus grandis from Site 2. Five specimens of each species were used at each site. Sampling was done in the late afternoon, when all species were actively feeding (Hammond, 1982). Only H. mexicana and I badionotus found feeding on apparently uniform sand in the heterogeneous habitat of Site 1 were used. Sediment samples were taken immediately adjacent to each animal, scraping only the top few millimetres of sediment. Samples were collected adjacent to each spatangoid at about $5 \mathrm{~cm}$ below the sediment surface, the level at which the animals feed. Powell (1977) indicated that the funnel-feeding apodan holothurian Leptosynapta tenuis derived most of its sediment intake from the top $3 \mathrm{~cm}$ of sediment, so samples for comparison with the foreguts of $H$. arenicola, also a funnel feeder, were taken to this depth beside the anterior end of each animal.

The occurrence of Meoma ventricosa in coarse sand in channels of the fore reef (Site 3) and in fine sand at the $-10 \mathrm{~m}$ contour of the lagoon adjacent to Site 2 , provided natural experimental situations in lieu of laboratory experiments, which were precluded by the very large quantities of sand required to accommodate their burrowing habits. Sampling of 5 animals and adjacent sediments at each location followed the procedures above. Plagiobrissus grandis occurred at both locations at only very low densities, and so was not sampled.

At Site 4, where Isostichopus badionotus, Actinopygia agassizi and Euapta lappa were found to feed on fine, detrital sediments adhering to bare or turfcovered limestone pavement, the faeces of 5 individuals of each species were collected. Hammond (1981) has shown that no significant changes in grain size occur between the fore- and hindguts of holothurians. Since the last 2 species feed only nocturnally (Hammond, 1982), sampling was done at night. E. lappa faeces, which are not produced as discrete pellets, were collected by placing animals in small containers to void their guts. The material upon which the 3 species were feeding could not be collected, as fines were lost when attempting to syringe or scrape samples.

All animals used in field collections and the following laboratory experiments were measured using methods described by Hammond (1982).

\section{Laboratory Experiments}

Sediment was collected from two locations in the lagoon: at Site 2 , and at the $-10 \mathrm{~m}$ contour, near to 
where the Meoma ventricosa were collected (above). The former area yielded medium sand, the latter fine sand, in both cases poorly sorted, providing a wide range of grain sizes and considerable overlap. The sediments were placed $3 \mathrm{~cm}$ deep in shallow water tables, $1.5 \times 0.5 \mathrm{~m}$, provided with running seawater to a depth of $6 \mathrm{~cm}$. Experience with deeper tanks confirmed the observations of Crozier (1918) and Trefz (1958) that holothurians tend to climb the sides of the container, avoiding feeding on the bottom. However, in the shallow trays, they were found to feed readily within a few hours, and subsequent behaviour appeared normal.

Holothuria mexicana and Isostichopus badionotus were collected from Site 1, large $H$. arenicola from Site 2. Actinopyga agassizi and Euapta lappa from Site 4, and $H$. grisea and small $H$. arenicola from the lower intertidal at Site 5. Five small (ca. $12 \mathrm{~cm}$ ) I. badionotus, and 1 very small specimen each of $I$. badionotus and $H$. mexicana (ca. $7 \mathrm{~cm}$ ) were collected from various locations in the lagoon; the low numbers reflect the rarity of small individuals (Hammond, in prep.). All animals were kept for several days to void their guts before being placed in the experimental water tables. The same specimens were used in experiments on both coarse and fine sediments.

A maximum of 5 small animals, or 3 of the large Holothuria mexicana, Isostichopus badionotus or Actinopyga agassizi were placed in one water table. Faeces of each animal were collected after several days acclimation. In most experiments 5 individuals of each species were used, each individual producing a sample, but 10 specimens each of $H$. grisea and the small $H$. arenicola were used, combining the faeces of 2 individuals to produce a sufficiently large sample. The faeces of the very small specimens of $H$. mexicana and $I$. badionotus were collected separately. Procedures identical to those used in the field were required to collect Euapta lappa faeces, at $04.00 \mathrm{~h}$. Five samples of sediment were collected from the tank at the start of each experiment, for comparison with the faeces.

\section{Scanning Electron Microscopy (SEM)}

The feeding tentacles (buccal podia) of all species except Holothuria grisea were examined by SEM. The holothurians were relaxed in isotonic magnesium chloride solution until no response to prodding was elicited, whereupon several tentacles were removed. The spatangoids were relaxed by chilling them in seawater almost to freezing. Despite the apparent relaxation, all tentacles, but particularly those of Euapta lappa, contracted when placed in Baker's formaldehyde. They were dehydrated through an alcohol series, critical-point dried, coated with gold and examined in a Cambridge Stereoscan S4.10.

\section{Treatment of Sediment Samples}

All samples were washed in fresh water, treated with a weak solution of sodium hypochlorite to remove organic matter, rinsed several times with fresh water, collected on filter paper by vacuum filtration, and dried at less than $50^{\circ} \mathrm{C}$. This procedure ensured that aggregation of grains did not occur. The sediments were sieved at $0.5 \varnothing$ intervals to $4.5 \varnothing$ on an ATM Sonic Sifter, Model L3P. The mean cumulative weight percent of each group of samples (sediments, foreguts or faeces) was plotted on standard sedimentological graph paper, from which the graphic mean and the inclusive graphic standard deviation (Folk, 1974) were calculated.

\section{Assessment of Selective Feeding}

The methods employed in the present study necessitate a strictly operational definition of selective feeding, as a difference in the size-frequency distributions of the available and ingested sediments. This fails to distinguish between changes resulting from the possession of structures which permit active selection of some grain sizes and/or rejection of others, and changes which are due only to the inability to handle particular sizes because of morphological constraints, such as body or mouth size. The former circumstance, which implies an adaptive basis for its existence, has not been sought in most studies (e.g. Whitlatch, 1974; Fenchel et al., 1975; Fenchel and Kofoed, 1976), or could not be demonstrated (Reid and Reid, 1969). Examples of the latter are known (Nichols, 1959; Mangum, 1964; Gordon, 1966; Powell, 1977), and usually impose relatively fixed upper or lower limits on the grain size utilized. However, the distinction between particle-size selection mechanisms and simple morphological constraints may be artificial or at best imprecise (e.g. Powell, 1977), and may have the same ultimate consequences for habitat partitioning. For these reasons, and in the absence of definitive, functional studies of how grain-size selection might be exercised by holothurians and spatangoids, the operational definition adopted here is the best approach.

Visual inspection of size-frequency distributions provides the best means for comparing sediment samples (Folk, 1974). Standard sedimentological measures of average size and sorting (e.g. graphic mean, inclusive graphic standard deviation) may be used to summarise size-frequency distributions. However, it is 
apparent that no single parameter is sufficient for identifying selective feeding, since misinterpretation of data or loss of useful information can result. The most obvious and widely used measure, difference in average grain size, is inadequate when used alone since very different size-frequency distributions may have the same average grain size (Folk, 1974). In such cases, better sorting of the gut sediment can imply preferential ingestion (e.g. Gladfelter, 1978). Conversely, even when differences in average grain size are found, poorer sorting of the gut sample suggests that a selective mechanism is unlikely to be operating. Therefore, comparisons of average grain size should always be evaluated by reference to other characteristics of the size-frequency distribution.

Conventional sedimentological statistics, if used circumspectly, are thus a useful means of expressing the results of grain-selection studies. The methods are also appropriate to small samples of fine grains which must be analysed microscopically (Friedman, 1958). Another commonly used set of statistics, the Electivity Indices of Ivlev (1961), confers disproportionate importance on small differences in the tails of a sizefrequency distribution, and minimizes the significance of differences in the central portion. Their application to continuously distributed variables, such as grain size, rather than to discrete class of data, as originally intended, leads to anomalous results which are dif-

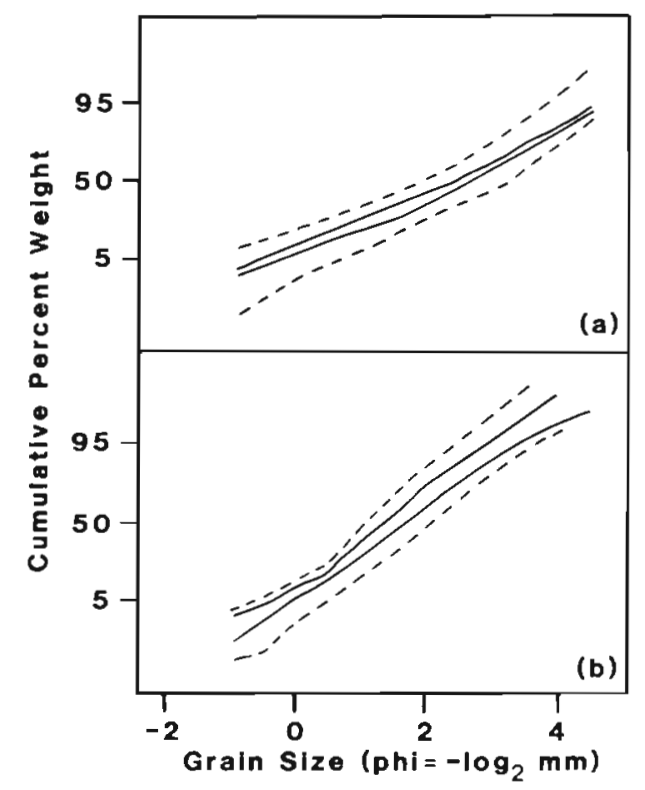

Fig. 2. Grain-size-frequency distributions of sediment sampled in the field. Each curve is the mean of 5 samples. (a) Distributions of 2 sets of samples (solid lines) collected at Site 1, 1 set adjacent to Holothuria mexicana, the other adjacent to Isostichopus badionotus. Broken lines are extremes of $95 \%$ confidence intervals of the 2 curves. (b) As in (a) for sets of samples collected at Site 2, adjacent to specimens of either Meoma ventricosa or Plagiobrissus grandis ficult to interpret, such as those of Powell (1977; his Tables 2 and 4). They contain no more information than the standard sedimentological statistics and present it in a less assimilable form, so their future use should be eschewed.

\section{RESULTS}

\section{Sieve Analyses}

The size-frequency distributions of the 2 sets of sediment samples from Site 1 (5 taken adjacent to Holothuria mexicana, 5 adjacent to Isostichopus badionotus) and the 2 sets from Site 2 (taken adjacent to Meoma ventricosa or Plagiobrissus grandis) are shown in Fig. 2a and b. All the size-frequency distributions were approximately normal. These data establish the variability of the sediment, which must be taken into account in subsequent interpretations of the foregut size-frequency distributions. The descriptive statistics derived from these curves and from graphical

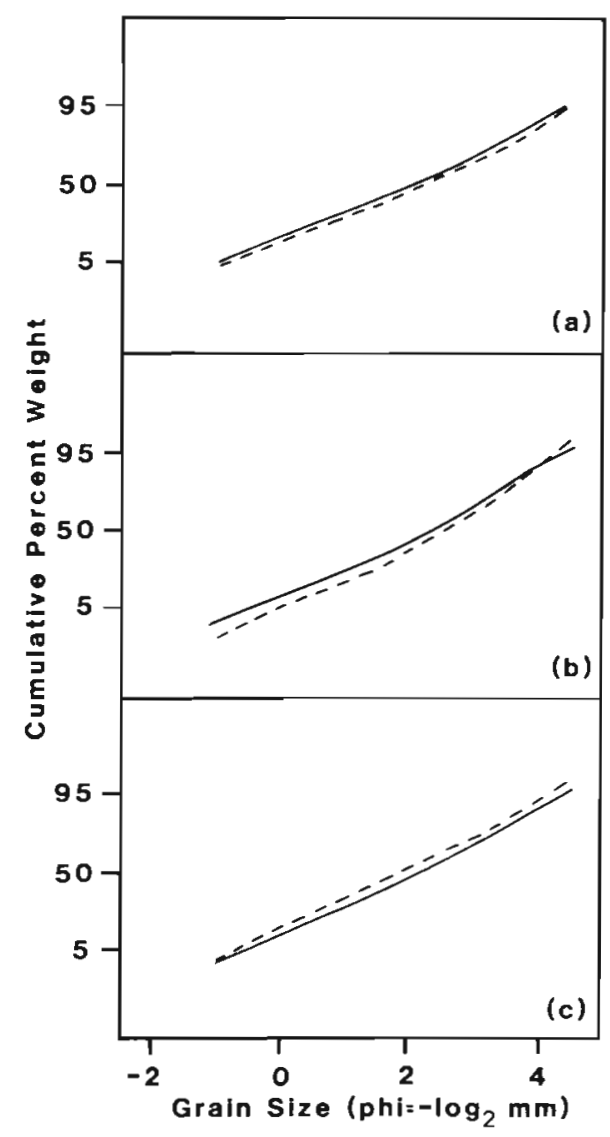

Fig. 3. Grain-size-frequency distributions of samples of adjacent sediments (solid lines) and foregut contents (broken lines) from 5 specimens each of (a) Holothuria mexicana, (b) Isostichopus badionotus, (c) H. arenicola, sampled at Site 1 
Table 1. Length (mean \pm standard deviation) of holothurians and echinoids sampled, and graphic mean and inclusive graphic standard deviation (sorting), in phi units, of ingested and available sediments from field collections

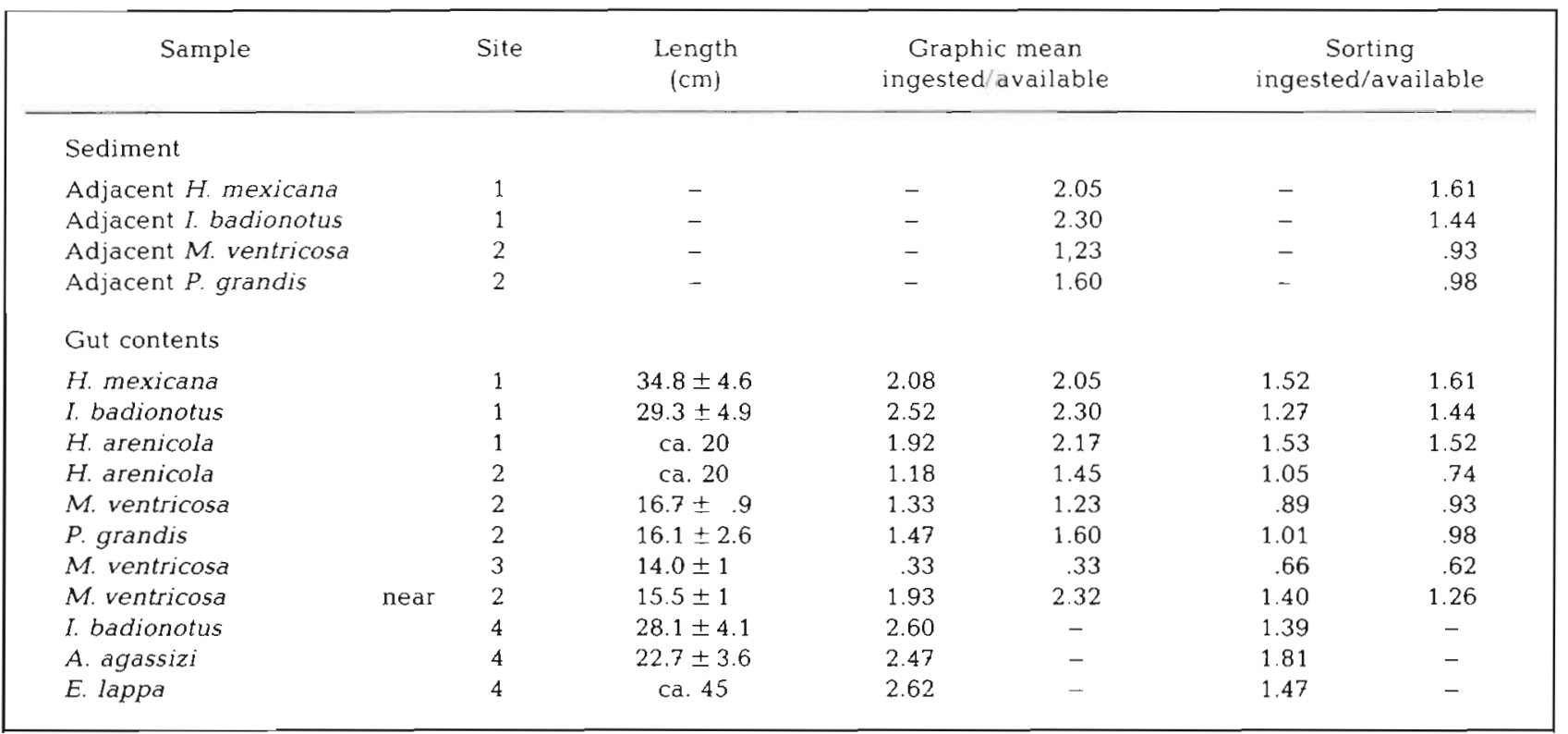

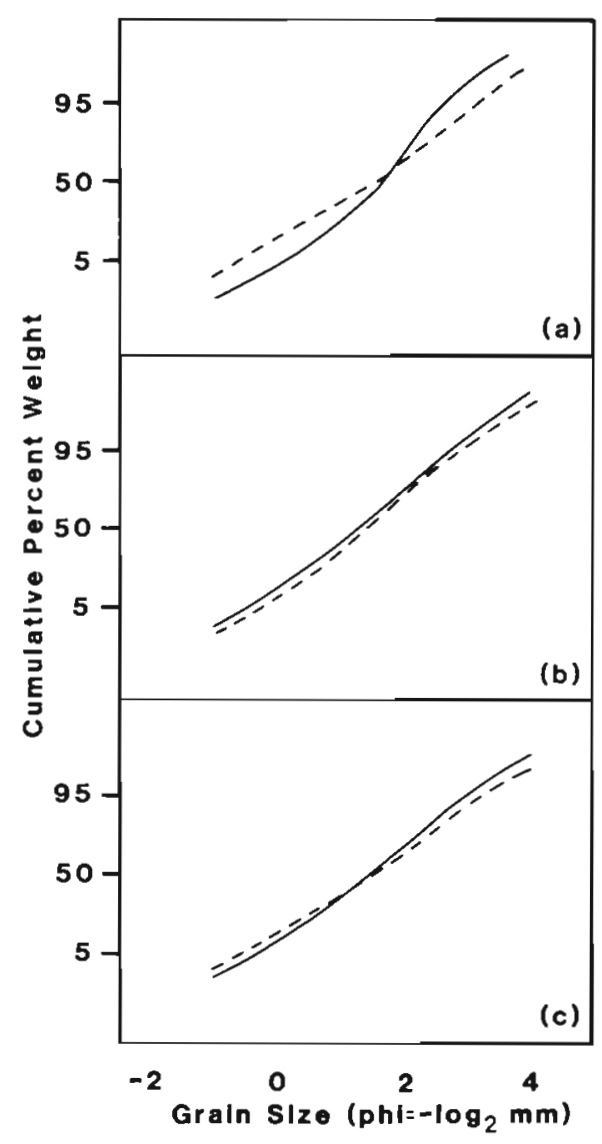

Fig. 4. Grain-size-frequency distributions of samples of adjacent sediments (solid lines) and foregut contents (broken lines) from 5 specimens each of (a) Holothuria arenicola, (b) Meoma ventricosa, (c) Plagiobrissus grandis, sampled at Site 2

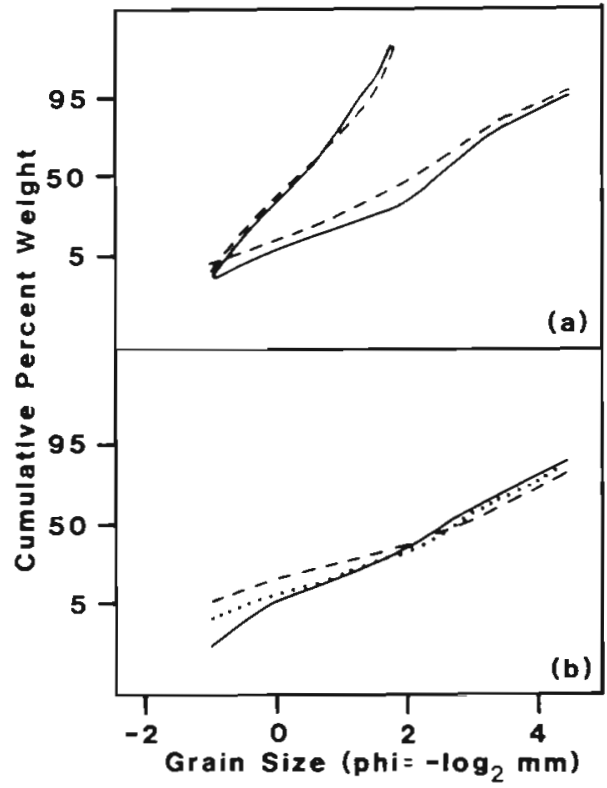

Fig. 5. Grain-size-frequency distributions of samples collected from (a) adjacent sediments (solid lines) and foreguts of Meoma ventricosa (broken lines) from coarse sand on the forereef (F) and in finer sand at the $-10 \mathrm{~m}$ contour in the western lagoon (L); (b) faeces of Isostichopus badionotus (solid line), Actinopyga agassizi (broken line) and Euapta lappa (dotted line) from Site 3 . Each curve is the mean of 5 samples

analysis of all other field collections are included in Table 1.

The results of the analyses of the foreguts of each species at Sites 1 and 2 are plotted with the appropriate sediment sample in Figs. $3(\mathrm{a}, \mathrm{b}, \mathrm{c})$ and $4(\mathrm{a}, \mathrm{b}, \mathrm{c})$. All 


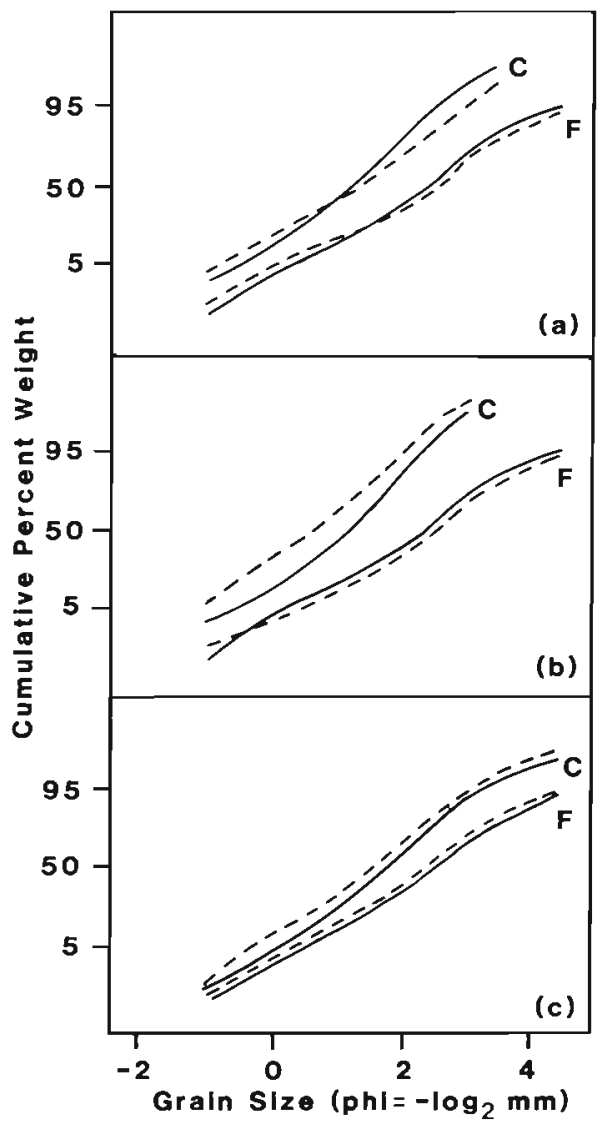

Fig. 6. Grain-size-frequency distributions of available sediments (solid lines, C: coarse, F: fine) and faeces (broken lines) from laboratory experiments utilizing (a) Holothuria mexicana, (b) Isostichopus badionotus, (c) $H$. arenicola

but 1 of the foregut samples conformed closely to the sediment samples, departing less from the sediment curve than other sediment samples (Fig. 2a, b). The exception, from the foreguts of Holothuria arenicola from Site 2, was slightly coarser but less well sorted than the sediment samples, which is considered to preclude any interpretation of selective feeding.

The foregut contents of Meoma ventricosa from the fore-reef and the $-10 \mathrm{~m}$ site in the lagoon also conform closely to the sediment from each location (Fig. 5a). Thus, over a range of grain sizes in different habitats, $M$. ventricosa displayed no preference, consuming all grain sizes in virtually the proportions in which they were available.

The 3 species of holothurians which co-existed at Site 4 egested sediments of approximately the same size-frequency distribution (Fig. 5b). This implies that they were indiscriminately ingesting the native sediment, or that each was discriminating in almost exactly the same manner.

The results of the laboratory experiments show that in all but a few cases, the size distribution of the sediment ingested by the holothurians closely resem-

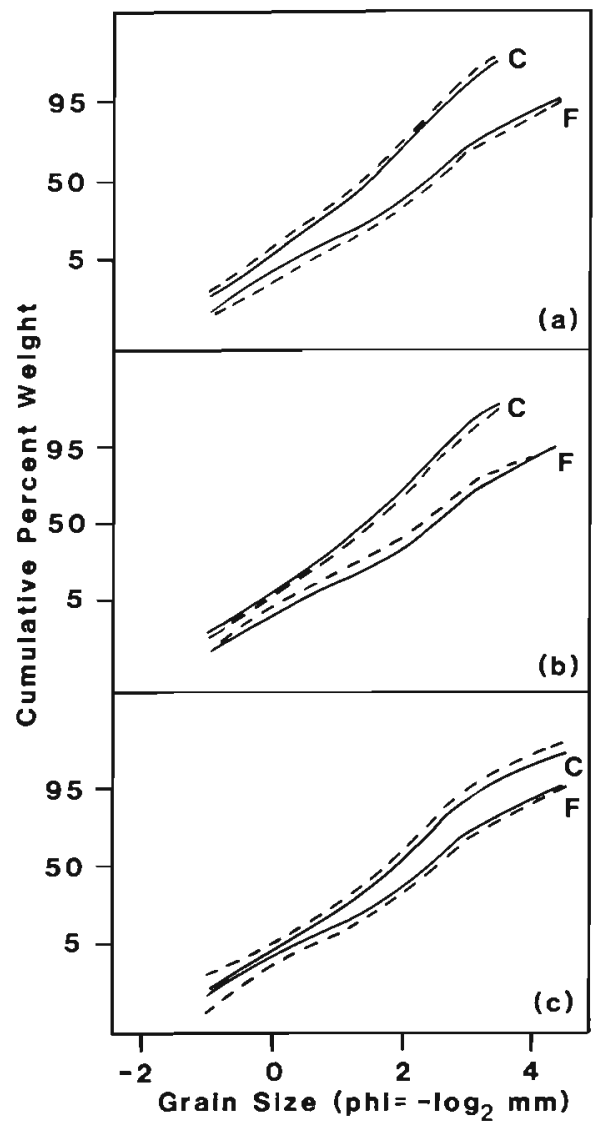

Fig. 7 Grain-size-frequency distributions of available sediment (solid lines, $\mathrm{C}$ : coarse, F: fine) and faeces (broken lines) from laboratory experiments using (a) Actinopyga agassizi, (b) Euapta lappa, (c) H. grisea

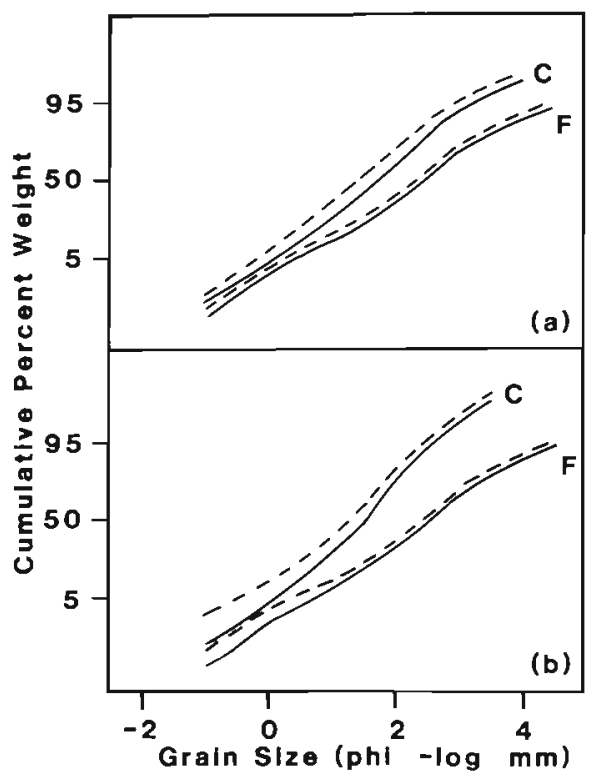

Fig. 8. Grain-size-frequency distributions of available sediment (solid lines, C: coarse, F; fine) and faeces (broken lines) from laboratory experiments utilizing (a) 5 small specimens of Isostichopus badionotus, (b) 10 small specimens of Holothuria arenicola. The sizes of the animals are given in Table 2 
Table 2. Length (mean \pm standard deviation) of holothurians used in laboratory experiments on selective feeding, and the graphic mean and inclusive graphic standard deviation (sorting), in phi units, of ingested and available sediments. Two sediment grades were supplied; $C$ denotes the coarser and $F$, the finer of these

\begin{tabular}{|c|c|c|c|c|c|c|}
\hline \multirow{2}{*}{$\begin{array}{c}\text { Species } \\
\text { H. mexicana }\end{array}$} & \multirow{2}{*}{$\begin{array}{c}\begin{array}{c}\text { Length } \\
(\mathrm{cm})\end{array} \\
32.2 \pm 5.1\end{array}$} & \multirow{2}{*}{$\begin{array}{l}\text { Grade } \\
\text { C }\end{array}$} & \multicolumn{2}{|c|}{$\begin{array}{c}\text { Graphic mean } \\
\text { ingested/available }\end{array}$} & \multicolumn{2}{|c|}{$\begin{array}{c}\text { Sorting } \\
\text { ingested/available }\end{array}$} \\
\hline & & & 1.33 & 1.42 & .83 & .84 \\
\hline & & $F$ & 2.45 & 2.42 & 1.11 & 1.16 \\
\hline \multirow[t]{2}{*}{ I. badionotus } & $29.1 \pm 3.8$ & $\mathrm{C}$ & 1.45 & 1.43 & .81 & .84 \\
\hline & & $\mathrm{F}$ & 2.18 & 2.40 & 1.26 & 1.14 \\
\hline \multirow[t]{2}{*}{ H. arenicola } & ca. 20 & $\mathrm{C}$ & 1.68 & 1.78 & .88 & .90 \\
\hline & & $\mathrm{F}$ & 2.52 & 2.45 & 1.09 & 1.16 \\
\hline \multirow[t]{2}{*}{ A. agassizi } & $22.7 \pm 3.6$ & C & 1.27 & 1.20 & 1.13 & .89 \\
\hline & & $\mathrm{F}$ & 2.40 & 2.43 & 1.24 & 1.14 \\
\hline \multirow[t]{2}{*}{ E. lappa } & ca. 45 & $\mathrm{C}$ & .65 & 1.17 & .96 & .82 \\
\hline & & $\mathrm{F}$ & 2.58 & 2.47 & 1.12 & 1.13 \\
\hline \multirow[t]{2}{*}{ H. grisea } & $12.0 \pm 2.1$ & $\mathrm{C}$ & 1.55 & 1.80 & .99 & .91 \\
\hline & & $F$ & 2.45 & 2.45 & 1.16 & 1.16 \\
\hline \multirow[t]{2}{*}{ I. badionotus } & $11.9 \pm 2.2$ & $\mathrm{C}$ & 1.42 & 1.73 & .94 & .93 \\
\hline & & $\mathrm{F}$ & 2.35 & 2.45 & 1.07 & 1.04 \\
\hline \multirow[t]{2}{*}{ H. arenicola } & $8.1 \pm 1.7$ & C & 1.20 & 1.47 & .80 & .70 \\
\hline & & $F$ & 2.53 & 2.43 & 1.04 & 1.15 \\
\hline \multirow[t]{2}{*}{ I. badionotus } & 7 & $\mathrm{C}$ & 1.52 & 1.77 & 1.02 & .92 \\
\hline & & $\mathrm{F}$ & 2.18 & 2.44 & 1.28 & 1.15 \\
\hline \multirow[t]{2}{*}{ H. mexicana } & 8 & $\mathrm{C}$ & 1.57 & 1.77 & .98 & .92 \\
\hline & & $F$ & 2.28 & 2.44 & 1.27 & 1.15 \\
\hline
\end{tabular}

bled that of the available sediment (Figs. 6a, b, c; $7 a$, c). In approximately half the experiments the ingested sediment was coarser than the available sediments, while in half it was finer, but the differences between the graphic means were slight, averaging $.09 \varnothing$ units (Table 2). Similarly, in half the cases the ingested sediments were slightly better sorted, while the remainder were more poorly sorted.

The tendency for the sediment ingested by Euapta lappa and the small specimens of Holothuria mexicana, Isostichopus badionotus and $H$. arenicola to be coarser than the available sediment in the experiments on 'coarser' sand (Figs. 7b, 8 a,b; Table 2) is considered to result from factors other than selective feeding. In all cases, difficultly was experienced in collecting faeces samples sufficiently large for sieve analysis. In the week which elapsed between sampling the sediments and obtaining the egested sediment samples, there was an observable coarsening of the surface sediments in the experimental tanks, apparently due to the activities of small infaunal organisms.

\section{Scanning Electron Microscopy}

Representative micrographs of the buccal podia of the holothurians and the 2 spatangoids are shown in Fig. 9. The surface of the aspidochirote holothurian feeding tentacles comprised discrete nodules, which, in the various species, were more or less arranged in larger groups. The number of nodules in each group varied considerably (e.g. $36 \pm 19$ in Isostichopus badionotus; Fig. 9a). The average diameter, as (longest + shortest axes) $/ 2$, of as many nodules or groups of nodules as were clearly visible on the photographs were measured with vernier calipers. In all cases, the sample size was greater than 10. Discrete groups of nodules were not easily identified in Holothuria arenicola and Actinopygia agassizi (Figs. 9 e,g), and so were not measured. The tentacles of the apodan Euapta lappa, shown in a contracted state in Figs. $9 \mathrm{i}, \mathrm{j}$, consisted of a central column with paired digits on either side. The surfaces of the digits had a tesselated appearance, but no suggestion of nodules.

Table 3. Mean and standard deviation of size of nodules or groups of nodules on the buccal podia of deposit-feeding holothurians and echinoids

\begin{tabular}{|lrl|}
\hline Species & $\begin{array}{c}\text { Nodule size } \\
(\mu \mathrm{m})\end{array}$ & $\begin{array}{c}\text { Group size } \\
(\mu \mathrm{m})\end{array}$ \\
\hline Holothurians & & \\
H. mexicana & $111 \pm 16$ & $701 \pm 71$ \\
I. badionotus & $122 \pm 8$ & $848 \pm 232$ \\
H. arenicola & $76 \pm 9$ & \\
A. agassizi & $80 \pm 12$ & \\
Echinoids & & \\
M. ventricosa & $76 \pm 4$ & \\
P. grandis & $76 \pm 5$ & \\
\hline
\end{tabular}




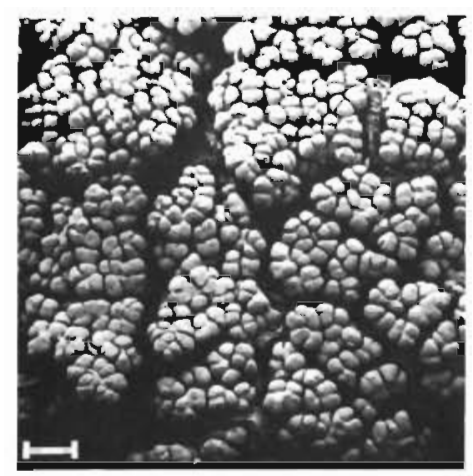

a

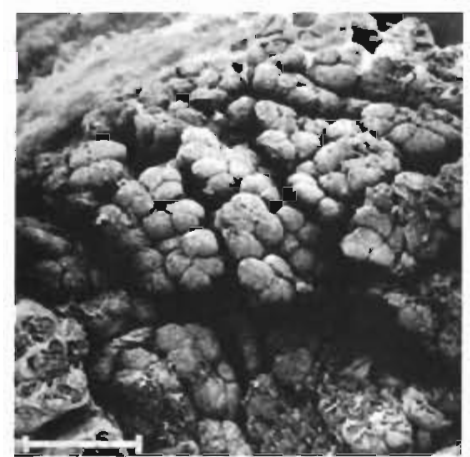

d

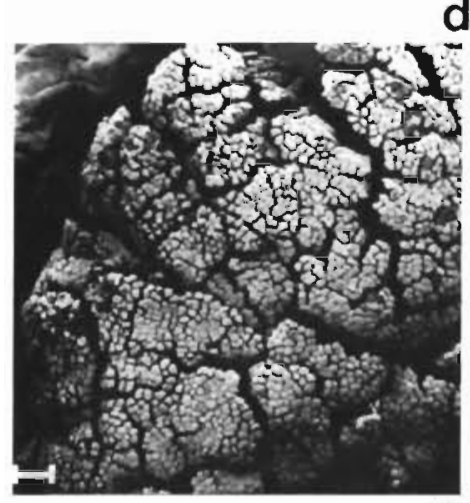

9

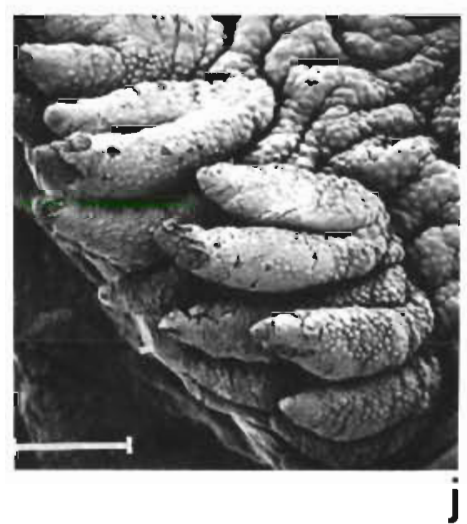

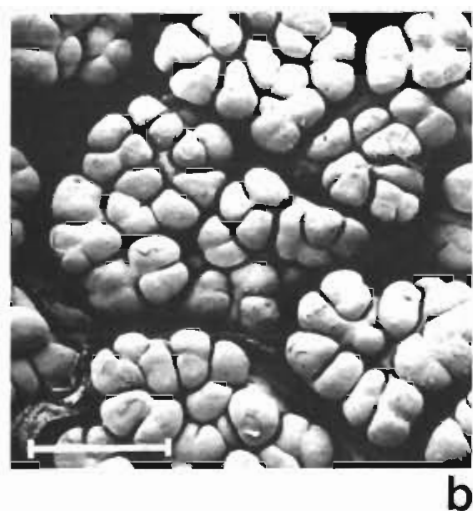

b

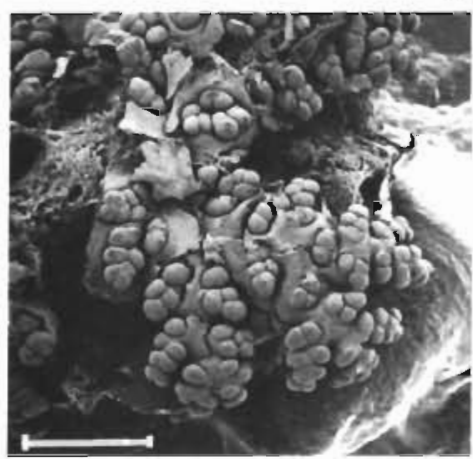

e

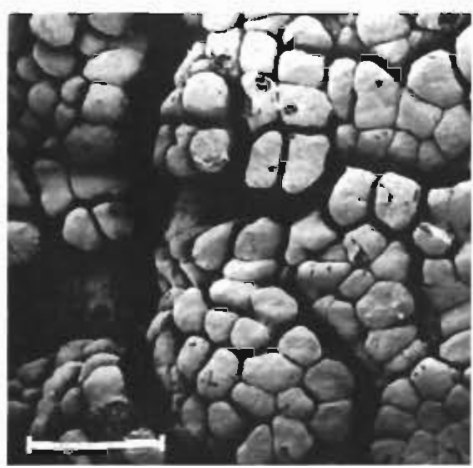

h

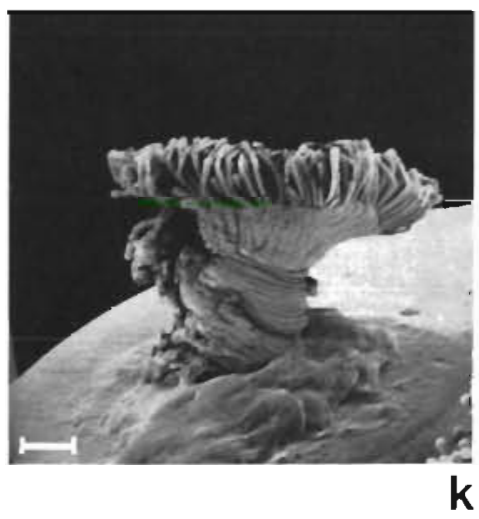

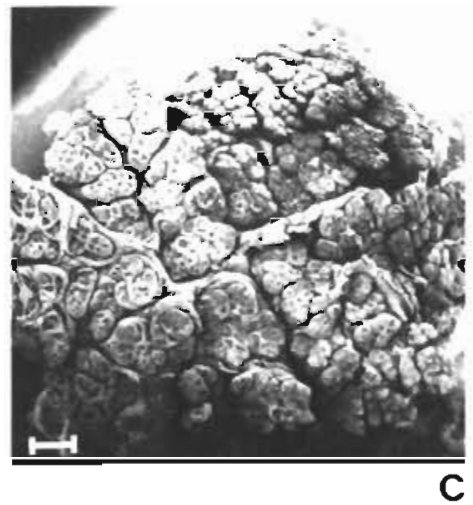

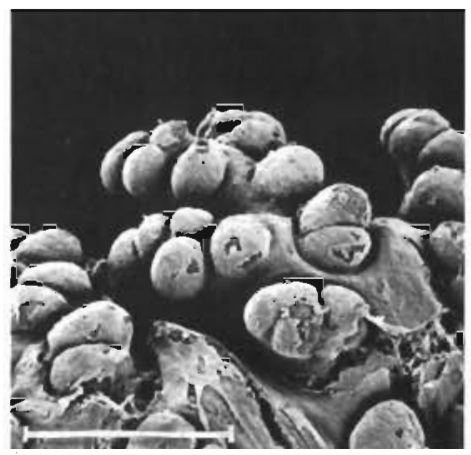

$f$
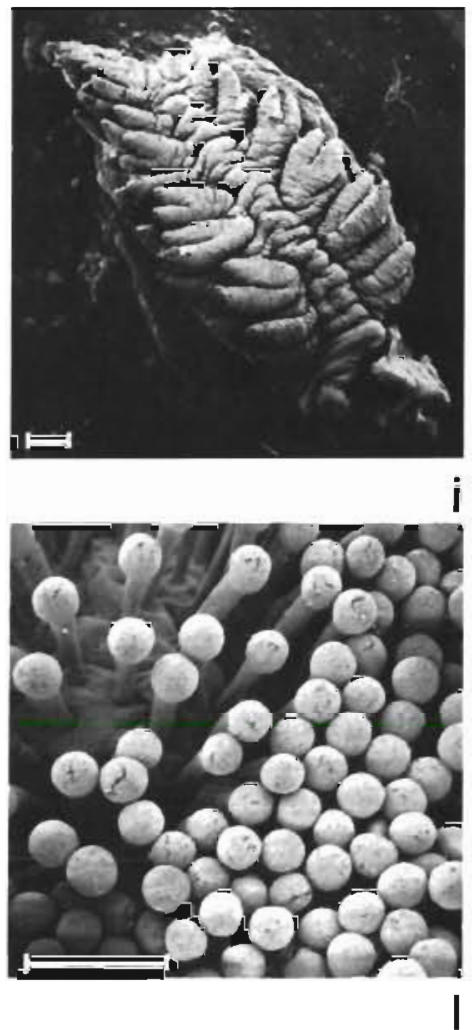

Fig. 9. Scanning electron micrographs of buccal podia of holothurians and spatangoids. (a, b) Isostichopus badionotus, (c, d) Holothuria mexicana, (e, f) H. arenicola, ( $g, h$ ) Actinopyga agassizi, (i, j) Euapta Lappa, (k) Meoma ventricosa, (l) Plagiobrissus grandis. Bar: $250 \mu \mathrm{m}$ in $\mathrm{f}, \mathrm{g}, 1,500 \mu \mathrm{m}$ in all other micrographs 
The 56 penicillate buccal podia of Meoma ventricosa, and the 38 of Plagiobrissus grandis were very similar in appearance. Each was a flat plate, several millimetres in diameter, bearing many closely-spaced, stalked, club-shaped projections (Fig. 9 k,l). The dimensions of the projections were measured for each species, but the distance between them was not recorded, as the podia had partially contracted upon fixation.

The dimensions of the textural features of the buccal podia of all species are listed in Table 3.

\section{DISCUSSION}

In all field collections and laboratory experiments, the moderately-to-poorly sorted sediments presented a wide 'choice' of particle sizes, upon which preference for particular grain sizes by the deposit feeders could be readily exercised. However, the results lead inescapably to the conclusion that the 6 holothurian and 2 spatangoid species are not capable of any selection of grain size when feeding. The close resemblance of the sediment ingested by the animals in the field to the available sediments does not alone provide this proof, since it might be argued that each species was occupying an optimal habitat. However, the close conformity between the size frequency distributions of the sediments offered experimentally, and those subsequently ingested, obviates this interpretation.

There was no significant evidence of different grainsize preference between small and large specimens of 3 species, Holothuria mexicana, Isostichopus badionotus and $H$. arenicola. The tendency of the small individuals to favour coarser grains in the experiment on 'coarse' sediment is considered an artefact resulting from altered conditions in the experimental tank. Moreover, it is improbable that small specimens would be able to select larger particles from the sediment when large ones showed no such ability (cf. McNulty et al., 1962; Whitlatch, 1974). If they did so, even greater departures in size distribution might be anticipated in the experiments carried out on 'fine' sediments; this proved not to be the case. Sloan and von Bodungen (1980) also found no evidence of particlesize selection by $I$. badionotus over a limited size range of animals. Similar results were obtained by Yanamouti (1939) for $H$. atra and Stichopus variegatus. Undoubtedly, at some small size, morphological constraints dictate an upper limit to the size of particles which may be ingested, but in all these studies, the animals tested were apparently beyond that size.

Previous reports of selective feeding by holothurians require reconsideration. The figures given by Bertram (1939) as evidence for preferential ingestion of small and large grains by Red Sea holothurians were based on combined gut samples of 4 species, which complicates their interpretation. They show that the sediment and foregut samples had almost identical means, but that the latter were more poorly sorted. These results are inconsistent with the criteria established for the determination of selective feeding in the preceding discussion. The holothurians studied by Emery et al. (1954) were feeding on sediments bound by an algal mat, which may have altered the availability of some size classes for ingestion, and thus led to the observed coarsening of the ingested sediments. This problem was not considered in their analysis of only 3 samples. The absence of a consistent trend in the comparison of sediment and samples from the foreguts of Holothuria atra by Emery (1962) precludes his interpretation that the animals 'are capable of some selection'. Hauksson's (1979) claim of selection of large grains from the sediment by Stichopus tremulus must be weighed against the different methods used to analyse the sediment from the two sources. Hauksson acknowledged, but did not resolve, this anomaly.

Yanamouti (1939; his Table 14) interpreted his results as indicative of selective feeding by 6 species. The significance of the slightly larger size of sediments ingested by Holothuria atra and Stichopus variegatus cannot be assessed, as the sample size was not given and the sediment heterogeneity was not measured. Powell (1977) rejected Yanamouti's claim of selective feeding by attributing the differences to the phenomenon of 'accessibility' of different-sized grains. This, however, was not evident in the present study, using sediments similar in composition, texture and fabric to those at Palau. The tendency of Stichopus chloronotus to ingest finer sands (Yanamouti; his Table 15) was discounted by Powell (1977) due to its propensity for moving through different sedimentary environments during the feeding cycle. Specimens of Actinopyga spp., although apparently preferring to consume fine sediments adhering to macrophytes in the field, did not exhibit any size selectivity in laboratory experiments (Yanamouti, 1939: 629).

Two studies have inferred selective feeding by comparing the gut contents of coexisting species of holothurians. Trefz (1956) studied 5 species from Hawaii, while Roberts (1979) investigated 12 species from a reef flat in Indonesia. In the absence of analyses of the available sediment, including an assessment of the heterogeneity of the substrate, conclusions that the species feed selectively cannot be sustained. Furthermore, there is evidence that tropical-reef holothurians display relatively stable microhabitat preferences (cf. Baker, 1929; Yanamouti, 1939; Bakus, 1968; Lawrence, 1979; Roberts, 1979) which may lead to consistent association with particular grades of sediment. The 
differences in grain size of the gut contents between species in the studies by Trefz (1956) and Roberts (1979), therefore, may be attributable only to microhabitat differences. Sloan (1979) indicated that similar differences between intertidal species from Aldabra was due to microhabitat selection on the basis of different body size.

The studies which show apparent grain-size selection by spatangoids may be criticized less readily, although some are contradictory. Nichols (1959) reported no selection by Echinocardium cordatum, but Lafon (1953), studying animals in a similar grade of sediment, found marked selection of larger grains. Three species were shown by Nichols (1959) to be unable to handle heavy grains which exceeded the adhesive strength of the mucous secretions of the feeding podia, but the effect of this phenomenon on grainsize-frequency distribution of ingested sediment was not investigated. The data of Lawrence and Ferber (1971) suggest that Lovenia elongata preferentially ingested particles with a median size of around $400 \mu \mathrm{m}$ from sediments which were, on average, either coarser or finer.

Thus, no studies have unequivocably demonstrated that deposit feeding holothurians are capable of exercising any preference for particular grain sizes. Generally, spatangoids also are non-selective feeders, particularly the large tropical species, although others may feed selectively. In contrast to many other deposit feeders (Fenchel et al., 1975), grain size does not appear to be a major axis of resource partitioning. In the few instances that particle size has been cited as the niche dimension along which coexisting species of holothurians differ (Trefz, 1956; Roberts, 1979; Sloan, 1979) the data probably reflect only a secondary correlation between sediment and habitat type. The theory of limiting similarity of coexisting species (MacArthur and Levins, 1967; Levins, 1968) requires that the number of resources available to an assemblage of species be equal to or greater than the number of species. Considering the abundance and diversity of coexisting species of tropical holothurians, particularly in Indo-West Pacific reefs, the omission of a conspicuous and, in studies of other taxa, apparently efficacious mechanism for resource partitioning such as grain size is perplexing. It is, however, consistent with the model developed by Taghon et al. (1978), which predicts that low time-specific assimilation efficiency will denote an optimum strategy of ingesting all particles as they are encountered in the environment. The 5 species sampled at Sites 1 and 2 had on average time-specific assimilation efficiencies of around $0.001 \mathrm{~min}^{-1}$ (Hammond, unpubl.). This lies at the lower limit of the range of values used by Taghon et al. (1978) to construct their model.
The absence of particle-size discrimination by holothurians and spatangoids in the present study obviates any direct relationship between grain size and the surface texture of the buccal podia. The analysis by Roberts (1979), which inferred such a relationship in holothurians from Indonesia, is inadequate in several respects. His failure to compare the gut sediment to those from the environment invalidates any interpretation based on grain selection. The purported relationship between nodular or group-nodular dimensions and grain size (Roberts, 1979; his Fig. 6) was based on a curious selection of data, the choice of which was not justified.

Witherto, purely mechanical models of particle gathering have been proposed for aspidochirote holothurians (Trefz, 1958; Roberts, 1979). In suspension-feeding dendrochirotes, adhesive secretions of the pharynx or buccal podia may facilitate particle entrapment (Fish, 1967; Fankboner, 1978). Some aspidochirotes have mucous glands in the pharyngeal wall (Hyman, 1955), and SEM photographs reveal an apparent coating of mucus on the buccal podia of several species in the present study (Figs. 9 and 10). A model of feeding which incorporates collection of sediment particles by adhesion to a mucous film would be consistent which the present indications that none of the species is capable of exercising grain-size discrimination. There is evidence for a similar 'adhesion' process in apodous holothurians (Powell, 1977) and in spatangoids (Nichols, 1959). The functional significance, if any, of the diversity of buccal podial surface textures may not be elucidated until a better understanding of the process of particle collection is achieved.

Acknowledgements. The micrographs were produced by Sharon Chambers, Lynn Rolph and Jeremy Woodley using the University of London Stereoscan Unit. Cathee Hammond performed many of the sieve analyses and Judy Bundy prepared most of the figures. The manuscript was critically read by Alastair Birtles, Ian Poiner and Jeremy Woodley. The facilities of the Discovery Bay Marine Laboratory and the Zoology Department, University of the West Indies, and the support of a Jamaican Award under the Commonwealth Scholarship and Fellowship Scheme are gratefully acknowledged.

\section{LITERATURE CITED}

Baker, J. R. (1929). On the zonation of some coral reef Holothuria. J. Ecol. 17: 141-143

Bakus, G. J. (1968). Defensive mechanisms and ecology of some tropical holothurians. Mar. Biol. 2: 23-32

Bertram, G. C. L. (1936). Some aspects of the breakdown of coral at Ghardaqa, Red Sea. Proc. Zool. Soc. Lond. (1936): 1011-1026

Cadée, G. C. (1976). Sediment reworked by Arenicola marina 
on tidal flats in the Dutch Wadden Sea. Neth. J. Sea Res. 10: $440-460$

Chesher, R. H. (1968). The systematics of sympatric species of West Indian spatangoids: a revision of the genera Brissopsis, Plethotaenia, Palaeopneustes and Saviniaster. Stud. Trop. Oceanogr Miami 7: VIII + $168 \mathrm{pp}$

Chesher, R. H. (1969). Contributions to the biology of Meoma ventricosa (Echinoidea: Spatangoida). Bull. mar. Sci. 19: $72-110$

Crozier, W. J. (1918). The amount of bottom material ingested by holothurians. J. exp. Zool. 26: 379-389

Emery, K. O. (1962). Marine geology of Guam. United States Geological Survey Prof. Pap. 403-B: 1-76

Emery, K. O., Tracey, J. I., Ladd, H. S. (1954). Geology of Bikini and nearby atolls. Part I. Geology. United States Geological Survey Prof. Pap. 260-A: 1-265

Fankboner, P. V. (1978). Suspension-feeding mechanisms in the armoured sea cucumber Psolus chitinoides (Clark). J. exp. mar. Biol. Ecol. 31: 11-25

Fenchel, T., Kofoed, L. H. (1976). Evidence of exploitative interspecific competition in mud snails (Hydrobiidae). Oikos 27: $367-376$

Fenchel, T., Kofoed, L. H., Lappalainen, A. (1975). Particle size selection of two deposit feeders: the amphipod Corophium volutator and the prosobranch Hydrobia ulvae. Mar. Biol. 30: 119-128

Fish, J. D. (1967). The biology of Cucumaria elongata (Echinodermata: Holothuroidea). J. mar. biol. Ass. U.K. 47: $129-143$

Folk, R. L. (1974). The petrology of sedimentary rocks, Hemphill Publishing Company, Austin

Friedman, G. M. (1958). Determination of sieve-size distributions from thin section data for sedimentary petrological studies. J. Geol. 66: 394-416

Gardiner, J. S. (1904). The fauna and geography of the Maldive and Laccadive Archipelagos, Vol. I, Cambridge University Press, Cambridge

Gladfelter, W. B. (1978). General ecology of the cassiduloid urchin, Cassidulus caribbearum. Mar. Biol. 47: 149-160

Glynn, P. W. (1965). Active movements and other aspects of the biology of Astichopus and Leptosynapta (Holothuroidea). Biol. Bull. mar. biol. Lab., Woods Hole 129: $106-128$

Gordon, D. C., Jr. (1966). The effects of the deposit feeding polychaete Pectinaria gouldii on intertidal sediments of Barnstable Harbour. Limnol. Oceanogr. 11: 327-332

Hammond, L. S. (1981). An analysis of grain size modification in biogenic carbonate sediments by deposit-feeding holothurians and echinoids (Echinodermata). Limnol. Oceanogr. 26: 898-906

Hammond, L. S. (1982). Patterns of feeding and activity in deposit-feeding holothurians and echinoids (Echinodermata) from a shallow back-reef lagoon, Discovery Bay, Jamaica. Bull. mar. Sci. 32, in press

Hansen, M. D. (1978). Nahrung und Freßverhalten bei Sedimentfressern dargestellt am Beispiel von Sipunculiden und Holothurien. Helgoländer wiss. Meeresunters. 31: $191-221$

Hauksson, E. (1979). Feeding biology of Stichopus tremulus, a deposit-feeding holothurian. Sarsia 64: 155-160

Hylleberg, J. (1975). Selective feeding by Abarenicola pacifica with notes on Abarenicola vagabunda and a concept of gardening in lugworms. Ophelia 14: 113-137

Hylleberg, J., Gallucci, V. F. (1975). Selectivity in feeding by the deposit-feeding bivalve Macoma nasuta. Mar. Biol. 32: $167-178$

Hyman, L. H. (1955). The invertebrates, Vol. IV, The echinodermata, McGraw-Hill, New York

Ivlev, V. (1961). Experimental ecology of the feeding of fishes, Yale University Press, New Haven

Lafon, M. (1953). Recherches sur les sables cotieres de la Basse-Normandie et sur quelques conditions de leur peuplement zoologique. Annales Inst. Oceanogr. 38: 113-161

Lawrence, J. M. (1979). Numbers and biomass of the common holothuroids on the windward reef flat at Enewetak Atoll, Marshall Islands. In: Jangoux, M. (ed.) Proceedings of the second European echinoderm colloquium, Brussels. A. A. Balkema, Rotterdam

Lawrence, J. M., Ferber, I. (1971). Substrate particle size and the occurrence of Lovenia elongata (Echinodermata: Echinoidea) at Taba, Gulf of Elat (Red Sea). Israel J. Zool. 20: $131-138$

Levins, R. (1968). Evolution in changing environments, Princeton University Press

MacArthur, R. H., Levins, R. (1967). The limiting similarity, convergence and divergence of coexisting species. Am. Nat. 101: 377-385

Mangum, C. P. (1964). Studies on speciation in maldanid polychaetes of the North American Atlantic coast. II. Distribution and competitive interaction of five sympatric species. Limnol. Oceanogr. 9: 12-26

McNulty, J. K., Work, R. C., Moore, H. B. (1962). Some relations between the infauna of the level bottom and the sediment in South Florida. Bull. mar. Sci. 12: 322-340

Newell, R. C. (1965). The role of detritus in the nutrition of two marine deposit feeders, the prosobranch Hydrobia ulvae and the bivalve Macoma balthica. Proc. Zool. Soc. Lond. 144: 25-45

Nichols, D. (1959). Changes in the chalk heart urchin Micraster interpreted in relation to living forms. Phil. Trans. R. Soc. Lond. B 242: 347-437

Powell, E. N. (1977). Particle size selection and sediment reworking in a funnel feeder, Leptosynapta tenuis (Holothuroidea, Synaptidae). Int. Revue ges. Hydrobiol. 62: $385-408$

Reid, R. B., Reid, A. (1969). Feeding processes of members of the genus Macoma (Mollusca: Bivalvia). Can. J. Zool. 47 : 644-657

Rhoads, D. C., Young, D. K. (1971). Animal sediment relations in Cape Cod Bay, Massachusetts. II. Reworking by Molpadia oolitica (Holothuroidea). Mar. Biol. 11: 255-261

Roberts, D. (1979). Deposit feeding mechanisms and resource partitioning in tropical holothurians. J. exp. mar. Biol. Ecol. 15: 69-80

Sloan, N. A. (1979). Microhabitat and resource utilization in cryptic rocky intertidal echinoderms at Aldabra Atoll. Seychelles. Mar. Biol. 54: 269-279

Sloan, N. A., von Bodungen, B. (1980). Distribution and feeding of the sea cucumber Isostichopus badionotus in relation to shelter and sediment criteria of the Bermuda platform. Mar. Ecol. Prog. Ser. 2: 257-264

Taghon, G. L., Self, R. F. L., Jumars, P. A. (1978). Predicting particle selection by deposit feeders: a model and its implications. Limnol. Oceanogr. 23: 752-759

Trefz, S. M. (1956). Office Naval Research Project NR 165-264

Trefz, S. M. (1958). The physiology of digestion of Holothuria atra Jager, with special reference to its role in the ecology of coral reefs. Ph. D. thesis, University of Hawaii

Whitlatch, R. B. (1974). Food-resource partitioning in the deposit-feeding polychaete Pectinaria gouldii. Biol Bull. mar. biol. Lab., Woods Hole 147: 227-235

Whitlatch, R. B. (1976). Methods of resource allocation in marine deposit-feeding invertebrates. Am. Zool. 16: 195

Woodley, J. D., Robinson, E. (1977). Field quidebook to the 
modern and ancient reefs of Jamaica, Atlantic Reef Committee, University of Miami

Yanamouti, T. (1939). Ecological and physiological studies on holothurians in the coral reef of Palao Islands. Stud. Palao Trop. Biol. Stat. 1: 603-636
Yingst, J. Y. (1974). The utilization of organic detritus and

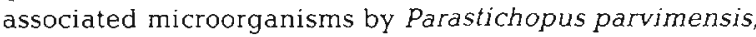
a benthic deposit-feeding holothurian. Ph. D. thesis, University of South California

This paper was presented by Dr. J. S. Bunt; it was accepted for printing on December 10, 1981 